\title{
Using Group Coaching to Foster Reflection and Learning in an MBA Classroom
}

\author{
Erek J. Ostrowski \\ Boston, USA
}

\begin{abstract}
Group coaching may facilitate individual learning and change over time through the social processes of learning vicariously and learning through feedback. While anecdotal evidence shows there may be potential benefits of applying group coaching to a graduate school learning environment, there are several challenges which warrant consideration. After examining the findings of Ostrowski's (2018) study of the individual learning and change processes involved in group coaching, this paper outlines the role of group coaching in the design and implementation of a three-course series in a graduate business program. The personal reflections of students in the program shed light on group coaching's potential benefits, yet research is needed to substantiate their claims. The paper concludes by considering some of the challenges of applying group coaching in the classroom.
\end{abstract}

Keywords: coaching, group coaching, coach training, group learning, MBA education

\section{Introduction}

Although coaching has achieved a degree of acceptance as a method of enriching the learning experiences of MBA students, little is known about how group coaching can be used to foster learning and change in the classroom. After examining the findings of Ostrowski's (2018) dissertation study on the individual learning and change processes involved in group coaching, this paper outlines the role of group coaching in the design and implementation of a threecourse series in a graduate business program.

The paper begins with a brief exploration of the literatures on group coaching and coaching in MBA education. An overview of the design, findings, and application of Ostrowski's (2018) study follows. The paper then explores anecdotal accounts from students in the program which suggest that group coaching may hold significant value in this context. The paper concludes with an examination of some of the challenges involved in using group coaching in an MBA classroom, along with some tentative recommendations for those who might wish to continue the exploration. 


\section{Background}

Coaching is a collaborative process that supports personal reflection and meaning making, as well as the achievement of specific personal or professional objectives (Grant, 2006; Stelter, 2012; Stern, 2004). Group coaching can be defined as the application of coaching principles (such as active listening, meaningful questioning, designing actions, and managing accountability) to a small group, across multiple sessions, facilitated by a skilled professional, and in service of individual, collective, personal, and/or organizational learning and goals (Ostrowski, 2018). Despite the fact that dyadic (one-on-one) coaching is now supported by a substantive and growing research base, knowledge of the subdiscipline of group coaching is still in its infancy (O'Connor \& Cavanagh, 2017; Passmore \& Fillery-Travis, 2011). As a result, the literature base is sparse, and conceptions of group coaching differ according to a variety of theoretical perspectives.

Group coaching includes the coaching of intact work teams in organizations (team coaching), as well as coaching that involves other types of groups that may or may not have an organizational focus (Brown \& Grant, 2010; Thornton, 2010). To date, researchers have given more attention to the study of organizational team coaching than to unaffiliated group coaching in which group members share no close affiliation outside of the coaching group itself. However, in its latter form group coaching is becoming increasingly popular among practitioners and consumers (Britton, 2013; Ward, 2008).

O'Connor and Cavanagh (2017) argued that this type of group can benefit members by helping individuals draw from the challenges, learning, and experience of the other group members; and by linking individuals across their different situations and contexts. Although coaching in an unaffiliated group setting may appear to have much in common with organizational team coaching, the differences between these two practice environments (outlined below in Table 1) are worthy of consideration. 
Table 1. Unaffiliated Group vs. Work Team Coaching

\begin{tabular}{llll}
\hline Characteristics & Unaffiliated groups & Work teams & Noted by \\
\hline Focus & $\begin{array}{l}\text { Individual goals and } \\
\text { objectives }\end{array}$ & $\begin{array}{l}\text { Team-level goals shared } \\
\text { by all team members }\end{array}$ & $\begin{array}{l}\text { (Britton, 2010, 2013; } \\
\text { Cockerham, 2011; } \\
\text { Hawkins, 2017) }\end{array}$ \\
Relationships & $\begin{array}{l}\text { Bounded by the } \\
\text { coaching agreement }\end{array}$ & $\begin{array}{l}\text { Pre-established (co- } \\
\text { workers or team members } \\
\text { in the same organization) }\end{array}$ & (Britton, 2010, 2013) \\
Setting & $\begin{array}{l}\text { Diverse - not } \\
\text { necessarily } \\
\text { organizational or } \\
\text { business-focused }\end{array}$ & $\begin{array}{l}\text { Organizational—within a } \\
\text { single organization }\end{array}$ & (Britton, 2010, 2013; \\
Approacherham, 2011) & $\begin{array}{l}\text { Horizontal - } \\
\text { comparable vocational } \\
\text { levels; no } \\
\text { hierarchically senior } \\
\text { team leader or manager }\end{array}$ & $\begin{array}{l}\text { Vertical-process focuses } \\
\text { leard toward team }\end{array}$ & 2014) \\
\hline
\end{tabular}

\section{Unaffiliated Group Coaching}

Past studies have shown group coaching of this type to foster meaning making, social support, and positive lifestyle changes; while offering valuable opportunities to gain perspective and learn from peers (Stelter, Nielsen, \& Wikman, 2011; Van Dyke, 2012; Whitley, 2013). Stelter et al. (2011) found group coaching to facilitate meaning making and social support in elite high school athletes. Participants in the study were coached to surface their personal processes of meaning making formed through both experience and tacit knowledge. As a result, they learned to share their experiences, thoughts, and reflections as part of a peer dialogue, and to collaboratively form new stories about challenging events and circumstances to convey them in a new light. Van Dyke (2012) investigated the experiences of 21 executives who participated in 19 different virtual group coaching programs. Her findings indicated that participants used their coaching groups as structures of accountability, as sounding boards for the discussion of business challenges, 
and as opportunities to gain business knowledge and self-insight as part of a facilitated peer dialogue.

Whitley's (2013) action research study explored how group coaching can be designed to support and facilitate lifestyle changes in people with long-term health conditions (LTC). The coaching focused on facilitating interaction between group members, SMART goal setting and subsequent action, and the development of a supportive peer environment in which participants could reflect on their experiences. Participants reported that the group helped them practice the skills needed to achieve their goals, thereby supporting them to make changes in their lives, and to cope with and manage their health conditions.

These studies support the idea that group coaching has the potential to foster critical reflection and to serve as a catalyst for meaningful learning and change. However, little is known about how these experiential and social learning processes unfold in a group coaching setting, or about the different types of contexts and populations which stand to benefit from group coaching. Thus, a research study was conducted to learn more about group coaching as a setting for social and experiential learning and change (Ostrowski, 2018). That study, which formed the basis for the present article, examined entrepreneurs' experiences navigating challenges, which they might otherwise face in isolation, within the context of a coaching group. The findings (detailed below) showed that group members engaged in dynamic and impactful processes of learning and change that unfolded over time and through specific sequences of events.

\section{Coaching in MBA Programs}

An increasing number of top-ranked graduate business schools have turned to coaching as a way of attracting students and preparing them for the challenges of workplace leadership roles (Itah, August 5, 2013; Steiner, Dixon, $\&$ Watson, 2018). Typically, these MBA programs use professional one-onone coaching to help students develop their leadership and communication skills, and/or to help them clarify their career trajectories (Parker, Hall, \& Kram, 2008). The hope is that providing students with specialized and personal support will better prepare them for the responsibilities of management and help them stand out in an increasingly competitive marketplace.

Professional coaching resources can be a costly addition for MBA programs (Itah, August 5, 2013). As a flexible and cost-saving alternative, 
Parker et al. (2008) recommend peer coaching, in which students form dyadic coaching partnerships with one another in order to foster personal learning and leadership development. They propose that the steps students take toward building developmental relationships, coupled with the intrinsic rewards of the learning they experience, help them internalize peer coaching skills and apply them in the future. As a result, peer coaching provides opportunities for students to benefit from being coached. But through providing coaching for their peers, students also incorporate coaching into their management and leadership repertoire (Ladyshewsky, 2006; Parker et al., 2008).

Organizations are increasingly seeking to use coaching in ways that transcend performance management and that enable them to cope more effectively with a complex and uncertain business world (Grant, 2016; Stacey $\&$ Griffin, 2005). As a result, more are acknowledging coaching's value and potential as a tool for navigating cultural and organizational change (Bickerich, Michel, \& O'Shea, 2017). Thus, teaching and embedding coaching skills in organizational leaders has become a major focus in leadership development. While business schools have warmed to the idea of providing coaching as a resource for students, business students also need to learn coaching skills in order to be prepared for the demands of organizational leadership. Peer coaching, when effective, can service both of these needs.

Group coaching, meanwhile, holds promise for MBA education beyond the typical dyadic relationship between coach and student, or between student peers. As mentioned above, small-group coaching can be an effective alternative for fostering personal learning and development. Groups involve and can make use of relational learning and change mechanisms that are not available in dyads (O'Connor \& Cavanagh, 2017). Many of these mechanisms, such as those described by Yalom and Leszcz (2005), have been welldocumented in a clinical context and adapted for use in group coaching (Kets de Vries, 2011, 2014; Thornton, 2010).

In addition, group psychotherapy research has demonstrated that participants in group therapy benefit from meeting people with similar problems, comparing their difficulties with others, and realizing they are not alone in their experiences (Danino \& Shechtman, 2012; Holmes \& Kivlighan, 2000). In fact, individuals actually experience the therapy of other group members - both through observation and through direct participation (Holmes \& Kivlighan, 2000). Ostrowski's study (2018) demonstrated that similar social processes can unfold through group coaching. 


\section{The Research Study}

The purpose of Ostrowski's (2018) study was to examine group coaching as a setting for individual learning and change in entrepreneurs. Entrepreneurs engage with a different set of challenges from the organizationally employedone that requires different avenues for learning and problem solving (Brett, Mullally, O'Gorman, \& Fuller-Love, 2012). The turbulent and non-linear nature of entrepreneurial firms makes entrepreneurial learning (EL) less likely to occur in a planned or programmatic way, and more likely to occur experientially, through action taken in response to lived experiences and real world situations (Deakins \& Freel, 1998; Higgins \& Aspinall, 2011).

Critical reflection is key to translating these events into actionable learning opportunities (Argyris \& Schön, 1978; Mezirow, 1991), however many entrepreneurs work in relative isolation and lack opportunities to engage with peers in meaningful reflection and learning (Gumpert \& Boyd, 1984; Zhang \& Hamilton, 2009). Since learning in small firms hinges on social interaction (Higgins \& Aspinall, 2011), these pressures contribute to the need for entrepreneurs to seek out and find social contexts that can support their learning and development. Group coaching offers one such context. Ostrowski (2018) sought to explore entrepreneurs' experiences navigating challengesthat they might otherwise grapple with in isolation - within the context of a coaching group. The research question was, what does it mean to entrepreneurs to navigate their learning-related challenges in the context of a coaching group?

\section{Methods}

The study used a qualitative approach and narrative methods of inquiry and analysis. In general, qualitative approaches are suitable when the research goal is to understand the meaning that participants attribute to specific events, situations, or other social phenomena (Creswell, 2009; Maxwell, 2013). Qualitative research emphasizes individual meaning, and often seeks to render the complexity of lived experience (Creswell, 2009). Narrative methods are used to explore the stories or storied descriptions of events that take place in the lives of individuals (Pinnegar \& Daynes, 2007; Polkinghorne, 2010). As such, narrative researchers seek to gather rich, storied descriptions of events. Attention is placed on the sequence and consequences of human activity, and on the context(s) surrounding the production of storied data (Bailey \& Jackson, 2003; Riessman, 2008). 


\section{Recruitment}

Recruitment for the study involved finding and contacting coaches who provide group coaching services for entrepreneurs, and then inviting individual group members to participate in the study. The study applied two sets of inclusion criteria - one for the group coaching programs and one for their group members. The inclusion criteria for group coaching programs closely followed the definition of group coaching offered above (the application of coaching principles to a small group, across multiple sessions, etc.). In order to be considered for inclusion in the study, individual participants needed to own or operate their own small businesses or entrepreneurial ventures as defined by the 1996 European Commission on small and micro enterprises (Deakins \& Freel, 2012), have a financial investment at stake in their businesses (exposure to risk), and have a history of actively participating in an eligible group coaching program for at least two months and at least three group sessions over time.

Nine participants met the criteria for inclusion and chose to participate in the study. Two participated in a pilot study and seven in the main study. Data from one of the pilot interviews were later added to the main study, bringing the total number of participants in the main study to eight (five female and three male). Six participants in the main study were referrals from two different groups led by the same group coach. The other two were each referred by different coaches and participated in separate group coaching programs.

\section{Data Collection}

Data collection was accomplished via one-on-one, semi-structured narrative interviews with each participant. Six interviews were conducted faceto-face, and three (including two pilot interviews) were conducted via Zoom web conference (audio only). The interviews ranged from 60-96 minutes in length. The interview protocol for this study was designed according to Kvale's (2007) recommendations for conducting semi-structured life-world interviews, and Chase's (2003) advice on interview questions in narrative research.

\section{Analysis}

The data were interpreted using separate and sequential narrative/performative and thematic analytical methods (Braun \& Clarke, 2006; Polkinghorne, 1995; Riessman, 2008) to produce an in-depth, multidimensional understanding of the data. 
The goal of a narrative/performative analysis is to configure the data elements into an over-arching and emergent higher-order plot or explanatory story of each interview. Ostrowski reviewed the interview transcripts, noting speech elements and their use, "scenes" portraying unfolding action and its result, and relevant contextual information. He then developed rich explanatory stories supported by quotes and specific examples from the data. Such an analysis brings to the surface "truths unique in their particularity" and grounded in human experience (Josselson \& Lieblich, 2003).

In contrast, the product of thematic analysis is a set of common elements or categories that stretch across multiple stories, participants, and events (Riessman, 2003, 2008). Ostrowski followed Braun and Clarke's (2006) method; which involved coding the transcript data and searching for themes; then reviewing, defining and naming the themes and weaving them together to create an overall story of the analysis.

\section{Findings}

Group members were found to have engaged in dynamic and impactful processes of learning and change. The study revealed a range of possible process moves reflecting individual and social processes of learning and change that unfold over time and through specific sequences of events. Two broad types or categories of moves emerged from the data: moves that demonstrated learning vicariously and moves that demonstrated learning through feedback.

\section{Learning vicariously}

Participants described specific instances of becoming deeply involved in another group member's unfolding experience, learning from that involvement, and applying their learning in specific ways. Their stories illustrated three different "modes" of engagement with their peers' experiences: through empathy, challenge, and observation. The content of their vicarious learning also differed. Stories were reflective of learning that encompassed new theories of effective action, new business tactics, and/or the evolution of the entrepreneurs' entrepreneurial identities.

Participants' ways of engaging, coupled with the content of their learning, formed three distinct but related process moves with varying impacts in the participants' lives: 
- Learning new theories of effective action by engaging empathetically in another group member's transition, which enabled the participant to capitalize on a new business opportunity.

- Learning about one's entrepreneurial "self" by observing or challenging another group member's idea or decision, which strengthened the participant's claims to entrepreneurial identity.

- Learning new business tactics by observing another group member's idea, which led the participant to develop a new product for her company.

\section{Learning through feedback}

Entrepreneurs benefit in multiple ways from receiving feedback from other group members. The participants told stories about receiving feedback from others in the group, learning from this exchange, and applying their learning in specific ways. Their stories revealed at least three different types of feedback that the entrepreneurs received: acknowledging latent skills, legitimizing personal values, and distinguishing habitual behavior. As above, the content of their learning through feedback differed. The stories they told demonstrated learning about new strengths or capacities, achieving new clarity about priorities, and developing new self-awareness.

The type of feedback given and the content of participants' learning combine to form distinct but related process moves which all revolve around the notion of learning through feedback:

- Developing new strengths or capacities through receiving feedback that acknowledges latent skills, resulting in the pursuit of a new business opportunity, and the creation of a new reflective practice.

- Achieving new clarity about priorities through receiving feedback that legitimizes personal values, resulting in more time spent with family and new claims to entrepreneurial identity.

- Acquiring new self-awareness through receiving feedback that helps distinguish habitual behaviors, resulting in new ways of approaching work and new claims to entrepreneurial identity. 


\section{Implications for Coaches and Coaching Educators}

The study holds several implications for coaches and coaching educators, as described below. First, the findings help establish the validity of group coaching as a platform for supporting meaningful learning and change on multiple levels. Second, they help distinguish group coaching in relation to dyadic (one-on-one) coaching. Third, they help define the role of the coach in group coaching. And finally, they lend support to a long-term view of the group coaching process.

\section{Supporting Meaningful Learning and Change}

Group members navigated different processes of learning and change, driven by vicarious experience and direct feedback. The findings were reflective of both lower-level (adaptive) learning, and higher-level (exploratory) learning, as defined by the literature (Burgoyne \& Hodgson, 1983; Higgins \& Aspinall, 2011). Lower-level learning - responding to changes, correcting problems, adopting new ideas and tactics, and so on-is common for entrepreneurs. Higher-level learning, on the other hand, is rarer. It involves critically examining the values and assumptions that guide one's understanding of effective action. Higher level learning, in effect, involves "learning how to learn" from experience (Cope \& Watts, 2000), which can result in new selfawareness and personal understanding. The findings suggest that group coaching can help individuals develop the skills and resources necessary for higher-level learning by (a) introducing new information and perspectives that stimulate critical reflection, (b) creating a supportive atmosphere that nurtures introspection and insight, and (c) providing encouraging feedback from peers that can legitimize new insight and self-knowledge.

\section{Distinguishing Group Coaching from Dyadic Coaching}

The findings further distinguish the subdiscipline of group coaching relative to dyadic (one-on-one) coaching. At issue are the distinctions that make group coaching uniquely itself. This study shows that a number of social processes support or enhance coaching in a group context. Most importantly, participants' meaningful experiences involved learning from peer feedback or learning vicariously by engaging in peers' experiences. These defining moments stemmed from group members' interactions with each other, as opposed to their interactions with their coaches alone. Thus, in group coaching, the coaching relationship expands beyond the dyad to encompass the entire group. As Thornton (2010) argued, this provides wider opportunities for 
reflection and exchange, and allows for more direct and less threatening feedback between individuals who are relatively equal in power.

These conclusions underline the appropriateness of using group psychotherapeutic theory (Foulkes, 1948, 1986; Yalom \& Leszcz, 2005) as a lens for group coaching research, education, and practice-building on the work of Kets de Vries (2014) and Thornton (2010) in this vein. Research in this area has shown, for example, that group treatment allows clients to learn from both seeking and providing help (Holmes \& Kivlighan, 2000), and that individuals in group psychotherapy experience greater session depth when other group members engage in vicarious learning (Kivlighan, 2011). Knowledge of group psychotherapeutic theory and research helps shed necessary light on some of the distinguishing characteristics of unaffiliated coaching groups.

\section{Understanding the Role of Group Coach}

The defining characteristics of group coaching discussed above hold implications for the coach's role. Since the group context allows members to both seek help and provide it (Holmes \& Kivlighan, 2000), group members shift in and out of these roles at different times. Whereas dyadic coaching casts the coach in role of helper and the client in the role of coachee, group coaching requires the coach to be aware of group members' emergent identities as helpers, and in essence, to support and enable the helping process wherever it shows up in the group. For the coach, this means stepping back from the role of primary helper and focusing instead on holding (Winnicott, 1971) the group and on facilitating coaching competency in others. A central role of the group coach, then, is to enable group members to be successful in their roles as both coachees and peer coaches, and to encourage productive interaction and movement between these roles.

\section{Supporting Learning Over Time}

Finally, the findings support Stelter's $(2012,2014)$ view that the role of the group coach includes collaborating with group members to promote critical reflection, meaning generation, and the invention of new narratives that impact on identity and self-concept. Part of this process involves helping group members reflect on and make sense of their learning over time. There is some debate in the literature as to whether single-day or short-term interventions such as those studied by Barrett (2006), Kets de Vries (2005, 2011, 2014), and Ward (2008), should actually be considered group coaching. Although intervention

styles such as these promote quick results or "change in a single session" 
(Ward, 2008, p. 73), others have defined group coaching as something that specifically happens over time.

Thornton (2010), for example, stated that a multi-session format is necessary in order to reinforce and build on previous learning through continued reflection. Brown and Grant (2010) stressed the iterative nature of "idea development" over multiple sessions (p. 41), and Stelter et al. (2011) noted that engaging in multiple sessions over time helped participants develop durable social networks with their peers in the group. This study builds on the latter, long-term perspective. It supports the idea that multiple sessions over time allow for certain experiential and social learning processes to unfold that cannot possibly unfold in a single session. In other words, group coaching may best be conceived as an experiential and recursively organized phenomenon that allows for (a) the unfolding of experience over time and (b) the revisiting of experience and its meaning by group members.

\section{Applications in MBA Education}

These conclusions help to explain why and how group coaching holds promise as a method of helping graduate business students learn to engage thoughtfully and reflectively with peers as part of a learning dialogue. As stated above, the metacognitive processes involved in learning to coach one's peers hold additional promise for students as they prepare for leadership roles in a complex and volatile business environment. This raises the question of how group coaching can be incorporated successfully into MBA classrooms such that students receive both the personal benefits of receiving coaching and the knowledge and skills required to effectively coach others. However, the use of group coaching in MBA classrooms has received scarce attention from researchers. What impact can group coaching make when integrated into an MBA program? What do business students need to learn or master in order to become skillful group coaches themselves? The next section explores these questions through a brief case example outlining the application of group coaching in the design of a three-course professional practicum series in a graduate business program.

\section{Group Coaching Pilot Program}

The three-course professional practicum series is part of an early-career track MBA program at a small, private college in the Northeast United States. The purpose of the practicum is to help students learn to reflect critically on their early professional experiences, incorporate their learning into their 
emergent notions about who they wish to be as business leaders, and be prepared for the types of highly complex challenges they will face as managers. The practicum uses group coaching in the classroom as a way of helping students learn to reflect on and make meaning of their experiences, and to acquire specific coaching skills which are highly desirable in today's organizations. Vicarious learning and peer feedback are fundamental to the program's design, which is described below.

\section{Group Coaching Goals}

The primary goal of the group coaching was to help students reflect on and make meaning of their professional experiences in real time. As part of their MBA curriculum, students were required to obtain internships in professional organizations. Group coaching was used as a vehicle for expressing and talking about issues that arose out of these professional experiences (i.e., interpersonal challenges, self-advocacy, time management, decision-making, etc.). A secondary goal of the group coaching was to teach students to be effective coaches with one another, so that the coaching groups could function as robust learning environments in the classroom, and so that the students would acquire transferable coaching skills that would enhance their leadership and professional contributions in their places of work. The group coaching model used in the practicum was organized to help achieve these goals.

\section{Group Coaching Model}

The coaching model utilized a four-part design incorporating core coaching principles, relevant contextual knowledge areas, supervised practice, and reflective writing:

1. Core Coaching Principles. Six group coaching principles (Appendix A) formed a starting point for familiarizing the students with coaching. The principles are grounded in the literature and the International Coaching Federation (ICF) competency model ("Core Competencies," n.d.). The students' assignments included readings that directly addressed each competency.

2. Relevant Contextual Knowledge. Readings and in-class discussions of knowledge areas relevant to leadership, professionalism, and organizational life. These included personal purpose, emotional intelligence, gender, power, networking, organizational culture, and managing change.

3. Supervised Practice: 
a. Students were given time at each classroom session to meet in small groups in order to share their own experiences, learn from others' experiences, receive coaching and feedback from peers, and provide coaching and feedback to peers, under the supervision of an experienced group coach.

b. Classroom time was devoted to discussing and practicing the coaching principles, and to viewing coaching issues and situations through the lenses of the relevant contextual knowledge areas.

c. Classroom time was devoted to debriefing the students' internship and group coaching experiences, identifying important takeaways, action steps and commitments, etc.

4. Reflective Writing. The students were assigned a series of reflective papers to help them consolidate and apply their learning from the course.

\section{Preliminary results}

Anecdotal evidence from the students' reflection papers suggests that group coaching experiences present value in the development of early career MBA students' thinking about themselves, about others, and about enabling others to be effective in a professional setting:

"[My experiences in the group] helped me realize that I have the ability to determine what my 'perfect' is rather than setting the standard so high it is unattainable and unrealistic."

"The coaching groups pushed me to be open with my peers about my thoughts and struggles. In sharing my personal experiences, I often found that many of us were going through similar situations."

"The coaching groups allowed the class to create a community where we could express our thoughts and work to solve challenges. The coaching sessions often helped me to uncover a new way of thinking about a problem."

"As the year went on, I improved at following my curiosity to help uncover the underlying roots to a problem. It became more natural for me to ask open-ended questions, which pushed the 
thought process of my peers to approach problem-solving in new ways."

These results are highly encouraging. However, a more systematic and controlled study is needed to understand students' experiences more fully. Likewise, further research is needed to determine whether and how group coaching in an MBA classroom differs from the dyadic peer coaching studied by Parker and her colleagues (2008) in a similar setting. For example, what does the group environment provide in this setting that a dyad does not provide? Do the key characteristics of effective coaching groups differ from those of dyads? If so, how?

Potter (2017) showed that coach training may actually lead to growth in students' cognitive ability measured in terms of hierarchical complexity (vertical development). Could incorporating group peer coaching (as outlined above) into an MBA program contribute to students' vertical development? If so, how does their development compare with that of students in traditional MBA programs? Also, what design factors or best practices should be taken into account when incorporating group coaching into an MBA offering?

\section{Emergent challenges}

The pilot revealed several challenges as well, which must be considered when using group coaching in an MBA classroom setting. The potential for deep learning and change though group coaching is fundamentally connected to the creation of a safe, trusting, and intimate group environment (Kets de Vries, 2011; Thornton, 2010). A central challenge of using group coaching in the classroom involves building this kind of trust among student peers and ensuring psychological safety. Another challenge involves looking beyond the coaching dyad. Typically, coaching involves two people - a coach and a coachee. In group coaching, the coach (or group member taking on the coaching role) must access the collective resources of the larger group by engaging other group members in the process. This could include posing questions to the whole group to help illuminate one group member's coaching issue or asking other group members to share their own personal reflections in order to deepen one individual's coaching inquiry.

Consensus feedback holds special weight in a coaching group (Ostrowski, 2018). In other words, when a group is unanimous in their feedback to a specific group member, the message often holds more weight in the coachee's mind than if the same message were delivered by the coach alone. A third 
challenge of using group coaching in the classroom involves learning to actively leverage consensus feedback. Finally, and unsurprisingly, elevating students' group coaching skills can prove challenging. Participants in a coaching group must learn to focus on listening actively and creating a context of empathy and curiosity rather than on giving advice or "solving" their peers" problems. This can be difficult for students to grasp in the beginning. One solution is to model effective coaching behavior. This may provide a scaffolding (Wood, Bruner, \& Ross, 1976) to assist students as they work to increase their competency as new coaches.

\section{Conclusion}

Group coaching appears to facilitate individual learning and change over time through the social processes of learning vicariously and learning through feedback. Although coaching in general has achieved a degree of acceptance as a method of enriching the learning experiences of MBA students, most studies focus on providing one-on-one professional coaching for students or dyadic peer coaching in the classroom. Little is known about how group coaching can be used to foster learning and change in a similar setting. This paper reviews findings that group coaching can indeed foster rich learning and change in entrepreneurs outside of the classroom. However, it also strengthens the case for incorporating group coaching into graduate business programs and calls for additional research in this area.

\section{References}

Argyris, C., \& Schön, D. A. (1978). Organisational learning: A theory of action perspective. Reading, MA: Addison-Wesley.

Bailey, D. M., \& Jackson, J. M. (2003). Qualitative data analysis: Challenges and dilemmas related to theory and method. The American Journal of Occupational Therapy, 57(1), 57-65.

Barrett, P. T. (2006). The effects of group coaching on executive health and team effectiveness: A quasi-experimental field study (Doctoral dissertation). Retrieved from ProQuest Dissertations and Theses database. (UMI No. 3227469)

Bickerich, K., Michel, A., \& O'Shea, D. (2017). Executive coaching during organisational change: a qualitative study of executives and coaches perspectives. Coaching: An International Journal of Theory, Research and Practice, 11(2), 117-143. doi:10.1080/17521882.2017.1407806

Braun, V., \& Clarke, V. (2006). Using thematic analysis in psychology. Qualitative Research in Psychology, 3(2), 77-101. 
Brett, V., Mullally, M., O'Gorman, B., \& Fuller-Love, N. (2012). The role of action research in the development of learning networks for entrepreneurs. Action Learning: Research and Practice, 9(2), 125-143. doi:10.1080/14767333.2012.685699

Britton, J. J. (2010). Effective group coaching: Tried and tested tools and resources for optimum coaching results. Mississauga, Ontario: John Wiley \& Sons Canada.

Britton, J. J. (2013). From one to many: Best practices for team and group coaching. Somerset, NJ: John Wiley \& Sons.

Brown, S. W., \& Grant, A. M. (2010). From GROW to GROUP: Theoretical issues and a practical model for group coaching in organisations. Coaching: An International Journal of Theory, Research and Practice, 3(1), 30-45.

Burgoyne, J. G., \& Hodgson, V. E. (1983). Natural learning and managerial action: A phenomenological study in the field setting. Journal of Management Studies, 20(3), 387-399.

Chase, S. E. (2003). Learning to listen: Narrative principles in a qualitative research methods course. In R. Josselson, A. Lieblich, \& D. P. McAdams (Eds.), Up close and personal: The teaching and learning of narrative research (pp. 79-99). Washington, DC: American Psychological Association.

Cockerham, G. (2011). Group coaching: A comprehensive blueprint. Bloomington, IN: iUniverse.

Cope, J., \& Watts, G. (2000). Learning by doing - An exploration of experience, critical incidents and reflection in entrepreneurial learning. International Journal of Entrepreneurial Behavior \& Research, 6(3), 104-124. doi:10.1108/13552550010346208

Core Competencies. (n.d.). International Coach Federation. Retrieved from https://coachfederation.org/core-competencies

Creswell, J. W. (2009). Research design: Qualitative, quantitative, and mixed methods approaches. Thousand Oaks, CA: SAGE Publications.

Danino, M., \& Shechtman, Z. (2012). Superiority of group counseling to individual coaching for parents of children with learning disabilities. Psychotherapy Research, 22(5), 592-603. Retrieved from http://www.ncbi.nlm.nih.gov/pubmed/22694319

Deakins, D., \& Freel, M. (1998). Entrepreneurial learning and the growth process in SMEs. The Learning Organization, 5(3), 144-155. doi:10.1108/09696479810223428

Deakins, D., \& Freel, M. (2012). Entrepreneurship and small firms (6th ed.). Maidenhead, UK: McGraw-Hill. 
Foulkes, S. H. (1948). Introduction to group analytic psychotherapy. In S. L. Garfield \& A. E. Bergin (Eds.), Handbook of psychotherapy and behaviour change (3rd ed.). New York, NY: Wiley.

Foulkes, S. H. (1986). Group analytic psychotherapy: Method and principles. London, UK: Karnac Books.

Grant, A. M. (2006). An integrative goal-focused approach to executive coaching. In D. R. Stober \& A. M. Grant (Eds.), Evidence based coaching handbook: Putting best practices to work for your clients. Hoboken, NJ: John Wiley \& Sons.

Grant, A. M. (2016). The third 'generation' of workplace coaching: creating a culture of quality conversations. Coaching: An International Journal of Theory, Research and Practice, 10(1), 37-53. doi:10.1080/17521882.2016.1266005

Gumpert, D. E., \& Boyd, D. P. (1984). The loneliness of the small-business owner. Harvard Business Review, 62(6), 18-24.

Hawkins, P. (2017). Leadership Team Coaching: Developing Collective Transformational Leadership (3rd ed.). New York, NY: Kogan Page.

Higgins, D., \& Aspinall, C. (2011). Learning to learn: A case for developing small firm owner/managers. Journal of Small Business and Enterprise Development, 18(1), 43-57. doi:10.1108/14626001111106424

Holmes, S. E., \& Kivlighan, D. M. (2000). Comparison of therapeutic factors in group and individual treatment processes. Journal of Counseling Psychology, 47(4), 478-484. doi:10.1037/W022-OI67.47.4.478

Itah, M. (2013). Executive treatment before the title: Coaching in b-schools. Poets \& Quants. Retrieved from https://poetsandquants.com/2013/08/05/executive-treatment-before-thetitle-coaching-in-b-schools/

Josselson, R., \& Lieblich, A. (2003). A framework for narrative research proposals in psychology. In R. Josselson, A. Lieblich, \& D. P. McAdams (Eds.), Up close and personal: The teaching and learning of narrative research (pp. 259-274). Washington, DC: American Psychological Association.

Kets de Vries, M. F. R. (2005). Leadership group coaching in action: The Zen of creating high performance teams. Academy of Management Executive, 19(1), 61-76.

Kets de Vries, M. F. R. (2011). The hedgehog effect: The secrets of building high performance teams. San Francisco, CA: Jossey-Bass.

Kets de Vries, M. F. R. (2014). The group coaching conundrum. International Journal of Evidence Based Coaching and Mentoring, 12(1), 79-91. 
Kivlighan, D. M. (2011). Individual and group perceptions of therapeutic factors and session evaluation: An actor-partner interdependence analysis. Group Dynamics: Theory, Research, and Practice, 15(2), 147160.

Kvale, S. (2007). Doing interviews. Los Angeles, CA: Sage.

Ladyshewsky, R. K. (2006). Peer coaching: A constructivist methodology for enhancing critical thinking in postgraduate business education. Higher Education Research \& Development, 25(1), 67-84. doi:10.1080/13600800500453196

Maxwell, J. A. (2013). Qualitative research design: An interactive approach (3rd ed.). Thousand Oaks, CA: SAGE Publications.

Mezirow, J. (1991). Transformative dimensions of adult learning. San Francisco, CA: Jossey-Bass.

O'Connor, S., \& Cavanagh, M. (2017). Group and team coaching. In T. Bachkirova, G. Spence, \& D. Drake (Eds.), The Sage handbook of coaching. Thousand Oaks, CA: SAGE Publications.

Ostrowski, E. J. (2018). Coming in from the cold: The experience of group coaching as a setting for entrepreneurial learning and change. (Doctoral dissertation). Retrieved from ProQuest Dissertations and Theses database. (UMI No. 10746488)

Ostrowski, E. J. (2019). Crticial reflection in coaching. Unpublished manuscript.

Parker, P., Hall, D. T., \& Kram, K. E. (2008). Peer coaching: A relational process for accelerating career learning. Academy of Management Learning \& Education, 7(4), 487-503.

Passmore, J., \& Fillery-Travis, A. (2011). A critical review of executive coaching research: A decade of progress and what's to come. Coaching: An International Journal of Theory, Research and Practice, 4(2), 70-88. Retrieved from http://www.tandfonline.com/doi/abs/10.1080/17521882.2011.596484\#. U0LK9sda6-o

Pinnegar, S., \& Daynes, J. G. (2007). Locating narrative inquiry historically. In D. J. Clandinin (Ed.), Handbook of narrative inquiry: Mapping a methodology. Thousand Oaks, CA: Sage Publications.

Polkinghorne, D. E. (1995). Narrative configuration in qualitative analysis. International Journal of Qualitative Studies in Education, 8(1), 5-23. Retrieved from http://dx.doi.org/10.1080/0951839950080103

Polkinghorne, D. E. (2010). The practice of narrative. Narrative Inquiry, 20(2), 392-396. doi:10.1075/ni.20.2.11pol 
Potter, P. (2017). Becoming a coach: The transformative learning and hierarchical complexity of coaching students. (Doctoral dissertation). (UMI No. 10258038)

Riessman, C. K. (2003). Narrative analysis. In M. S. Lewis-Beck, A. Bryman, $\&$ T. Futing Liao (Eds.), The Sage encyclopedia of social science research methods (Vol. 1-3). Thousand Oaks, CA: Sage Publications.

Riessman, C. K. (2008). Narrative methods for the human sciences. Los Angeles, CA: Sage Publications.

Rogers, J. (2009). Coaching skills: A handbook(2nd ed.). Maidenhead: Open University Press.

Senge, P. M. (2006). The fifth discipline: The art and practice of the learning organization. New York, NY: Doubleday/Currency.

Stacey, R. D., \& Griffin, D. (2005). A complexity perspective on researching organizations: Taking experience seriously. London: Taylor \& Francis.

Steiner, S., Dixon, D. P., \& Watson, M. A. (2018). MBA coaching program: Best practices for success with limited resources. Management Teaching Review, 3(1), 86-97.

Stelter, R. (2012). A guide to third generation coaching: Narrativecollaborative theory and practice. Dordrecht, The Netherlands: Springer.

Stelter, R. (2014). Third generation coaching: Reconstructing dialogues through collaborative practice and a focus on values. International Coaching Psychology Review, 9(1), 51-66.

Stelter, R., Nielsen, G., \& Wikman, J. M. (2011). Narrative-collaborative group coaching develops social capital - a randomised control trial and further implications of the social impact of the intervention. Coaching: An International Journal of Theory, Research and Practice, 4(2), 123-137.

Stern, L. R. (2004). Executive coaching: A working definition. Coaching Psychology Journal: Practice and Research, 56(3), 154-162.

Stober, D. R., \& Grant, A. M. (Eds.). (2006). Evidence based coaching handbook: Putting best practices to work for your clients. Hoboken: John Wiley \& Sons, Inc.

Thornton, C. (2010). Group and team coaching: The essential guide. New York, NY: Routledge.

Van Dyke, P. (2012). Virtual group coaching: The experience of business professionals in the process. (Doctoral dissertation). Retrieved from ProQuest Dissertations and Theses database. (UMI No. 3546895)

Van Dyke, P. (2014). Virtual group coaching: A curriculum for coaches and educators. Journal of Psychological Issues in Organizational Culture, 5(2), 72-86. 
Ward, G. (2008). Towards executive change: A psychodynamic group coaching model for short executive programmes. International Journal of Evidence Based Coaching and Mentoring, 6(1), 67-78.

Whitley, S. (2013). Group coaching as support for changing lifestyle for those diagnosed with a long-term condition. International Journal of Evidence Based Coaching and Mentoring(Special Issue 7), 82-89.

Whitworth, L., Kimsey-House, K., Kimsey-House, H., \& Sandahl, P. (2009). Co-active coaching: New skills for coaching people toward success in work and life (2nd ed.). Boston, MA: Davies-Black.

Winnicott, D. W. (1971). Playing and reality. London, UK: Penguin.

Wood, D., Bruner, J., \& Ross, G. (1976). The role of tutoring in problem solving. Journal of Child Psychology and Child Psychiatry, 17, 89-100.

Yalom, I. D., \& Leszcz, M. (2005). The theory and practice of group psychotherapy. New York, NY: Basic Books.

Zhang, J., \& Hamilton, E. (2009). A process model of small business ownermanagers' learning in peer networks. Education + Training, 51(8/9), 607-623. 


\section{Appendix A: Coaching Principles}

Generate Dialogue (Senge, 2006)

- Suspend judgments and opinions

- Explore issues from multiple perspectives

- Nurture a collective understanding

- Facilitate meaning making

Listen Actively (Rogers, 2009)

- Be patient

- Let go of your own agenda

- Listen to what's not being said

- Show that you're listening and that you understand

Question Powerfully (Rogers, 2009)

- Ask open-ended questions

- Clarify understanding

- Deepen the inquiry

Reflect Critically (Ostrowski, 2019)

- Surface underlying beliefs and assumptions

- Focus on values

- Look inward

Design Actions (Stober \& Grant, 2006)

- Break large projects down into manageable chunks

- Find the highest leverage point

- What and by when?

Manage Accountability (Rogers, 2009; Whitworth, Kimsey-House, KimseyHouse, \& Sandahl, 2009)

- Track commitments

- Follow up on committed actions

- Address incompletions 